\title{
The Preparation of the
}

\section{Standards for College Libraries}

The Standards for College Libraries were prepared by the Committee on Standards, ACRL. The following members of the committee participated in drafting the standards: Felix E. Hirsch, Trenton State College, chairman; Mrs. Minnie Bowles, Chicago Teachers College; Helen M. Brown, Wellesley College; Eugene Holtman, Ohio State University; Donald O. Rod, Iowa State Teachers College; Roscoe Schaupp, Eastern Illinois University; Ruth Walling, Emory University; Helen M. Welch, University of Illinois.

At the ALA meeting in Kansas City, June 1957, the ACRL Board of Directors authorized the committee to proceed with the preparation of the new standards for college libraries. The earlier phase of the committee's work were described by Felix E. Hirsch, "Facing the Future: On the Way to New College Library Standards," CRL XIX (1958), 197-200, 262. At the ALA Conference in San Francisco, the committee held an open meeting on July $15,195^{8}$, to clarify the fundamental issues. Speakers at this large gathering included Flora B. Ludington, Mount Holyoke College; Wyman W. Parker, Wesleyan University; Eileen Thornton, Oberlin College; Paul Bixler, Antioch College; William Carlson, Oregon State System of Higher Education, and the committee chairman. Their comments were followed by an extended membership discussion. (A detailed report on the meeting, prepared by Helen M. Welch, is available from the office of the chairman.)

The committee consulted also with many other leaders of the library profession, with the executive secretaries of the regional accrediting agencies, and with more than thirty outstanding college presidents from all parts of the country, before the final draft of the standards was approved by the ACRL Board of Directors.

In an article for an early issue of the ALA Bulletin the committee's chairman writes: "The committee's main aim was to provide flexible standards, based on firm principles. It was felt that only an instrument that met both requirements would serve American higher education effectively in a period of tremendous expansion and fundamental changes. Many a college librarian will find it difficult to preserve the accustomed quality of library service in this era of sudden growth and emergent new trends. It is the hope of the new committee that the new standards may help not only to maintain, but even to strengthen the position of the college libraries in this period, particularly those which are already struggling against insufficient support or lack of recognition." 


\section{Standards for College Libraries}

$\mathrm{T}$ HESE STANDARDS are designed to provide a guide for the evaluation of libraries in American colleges and universities which emphasize four-year undergraduate instruction and may or may not have graduate programs leading to a Master's degree. They are not applicable, however, to junior college libraries nor to libraries of academic institutions stressing advanced research. For simplicity's sake, the term "college library" is used throughout rather than a long phrase such as "library in a college or university granting Bachelors' or Bachelors' and Masters' degrees."

\section{Functions of the College Library}

The college library should be the most important intellectual resource of the academic community. Its services, given by a competent staff of adequate size, should be geared to implement the purposes of the college's general program and to meet the specific educational objectives of the institution. Its collections should aim at presenting the heritage of Western and Eastern thought in all its richness, but should stress those particular areas which are central to the curriculum of the institution. No artificial barriers should separate the library from the classroom or the library staff from the teaching faculty. Beyond supporting the instructional program to the fullest extent, the library should endeavor to meet the legitimate demands of all its patrons, from the senior professor engaged in advanced research to the freshman just entering upon the threshold of higher learning, to stimulate and encourage the student to develop the lifelong habit of good reading, and to play its proper role in the community and in the wider realm of scholarship beyond the campus.

The standards laid down in this document must always be interpreted in the light of the aims and needs of the institution of which the library is a part.

This document was prepared by the ACRL Committee on Standards, Felix $E$. Hirsch, Chairman.

\section{Structure and Government}

If the institution's board of control has a committee on the library, its duties and authority should be clearly defined, and the relationship of the librarian to the committee should be stated. The committee should be concerned with general library policy and not with matters of an administrative and executive nature.

The librarian should be directly responsible to the president. Since the library is an important department serving the entire institution, the librarian should rank with other chief administrative officers. However, since he is concerned primarily with the academic program of the institution, he will work in a particularly close relationship with the head of the academic program. The librarian should be a member of the college planning group for the curriculum and of any other committee whose activities will vitally affect the future of library service.

As a rule, there should be a faculty library committee. The committee should act strictly in an advisory capacity. It should consist of both senior and junior faculty members, carefully chosen for their demonstrated understanding of library problems and for their willingness to take a genuine interest in the collections beyond those pertaining to their own departments. The committee should interpret the problems and policies of the library to the faculty and, in turn, make suggestions for the improvement of library service. It may also represent the faculty in the apportionment of book funds, insofar as they are allocated to the departments. The librarian should be a regular member of the committee and may serve as its chairman.

Wherever circumstances permit, a student committee on the library should be established to provide for a better liaison with the student body. Such a committee should be carefully selected and its functions properly defined; it should work closely with the librarian.

The librarian should always be entrusted with planning and administering the li- 
brary budget. No action affecting the library finances should be taken by administrative officers of the college without prior consultation with the librarian. All materials purchased from library funds or books and periodicals otherwise acquired by the institution should be considered a part of the library and should be under the control of the librarian.

The organization of the library should be logical and suitable to the institution. Lines of authority should be clearly drawn and should not cross. While the librarian must assume responsibility for the administration of the library, he should seek the advice of members of his staff on important matters of policy and procedure. Channels of communication within the staff should be well defined and generally understood.

The librarian must keep such statistical records as are necessary to give a clear picture of the activities, acquisitions, and use of the library. He should keep and regularly report statistics as requested by the United States Office of Education, regional accrediting agencies, and the Association of College and Research Libraries.

\section{BUDGET}

The funds provided for the support of the library will in large measure determine the quality of the library resources and services. The library's holdings, the prevailing methods of instruction, the size of faculty and student body, the extent to which the college encourages and provides for individual study, and the variety of graduate offerings are factors which influence the budgetary needs of the library.

The library budget should be determined in relation to the total budget of the institution for educational and general purposes. ${ }^{1}$ The program of library service outlined in these standards will normally require a minimum of 5 per cent of the total educational and general budget. ${ }^{2}$ The percentage must be higher if the library's holdings are seriously deficient, if there is

\footnotetext{
1 "Educational and general" is defined by the U. S Office of Education as operating funds used to defray expenditures for administration, instruction, research, extension services, plant operation and maintenance, and organized activities related to instructional departments.

2 This figure is suggested by an analysis of the statistics annually published by $C R L$ in its January issue.
}

rapid expansion in student population or course offerings, or if the institution fosters a wide range of studies at the Master's level or programs of independent study. While the allocation of library funds for specific purposes will depend on the needs of the individual institution, experience shows that a good college library usually spends twice as much (or more) for salaries as it does for books.

It should be considered a serious danger signal by the college authorities if the library budget sinks appreciably below the median ratio of library expenditures to total educational and general institutional expenditures for comparable institutions as indicated in the latest annual college library statistics.

\section{STAFF}

The library should be operated by a broadly educated and highly qualified staff of professional librarians, under the direction of a chief librarian. The professional librarian is defined as one holding a graduate library degree.

The size of the staff will vary with the size of the institution, but three professional librarians constitute the minimum number required for effective service, i.e., the chief librarian and the staff members responsible for readers services and technical processes. In addition to student enrollment, several other factors are important in determining the number of librarians needed, such as the type of organization within the library, the size and character of the collections, the teaching methods prevailing in the institution, the number of hours during which the library is open, and the arrangement of the building. At least one professional librarian should be on duty at all times during which the library is open for full service.

In addition to the professional librarians, the library should have an adequate nonprofessional staff. The ratio of professional to non-professional staff will vary according to the specific needs of institutions. Great care should be taken that professional staff members do not spend their time in doing work that is essentially of a clerical nature. Student assistants may be employed effectively in a variety of tasks, but, as a rule, they cannot be expected to 
perform the same kind of indispensable services that competent clerical workers will.

As the size of the library increases, the ratio of the non-professional to the professional staff should be larger. While it may be impossible to have uniform standards for the size of the staff, attention should be called to the formulas designed in certain states, which appear to present reasonable patterns within which most institutions can develop their programs of library service. ${ }^{3}$ Professional librarians should have faculty status, with the benefits enjoyed by the teaching staff. These should include such items as tenure, sick leave, liberal vacations, an adequate retirement plan, and sabbaticals. The salary schedule for librarians should be the same as for teaching members of the faculty. It follows that librarians-in line with the established promotion policies at their institution-should be expected to do graduate work in such areas as would contribute to their effectiveness in their respective positions. In some instances such a program of study might well lead to a second or third Master's degree rather than to a Ph.D. degree. Opportunity should be granted for engaging in such studies. However, provision should also be made for giving recognition through promotion or salary increase to exceptional ability in the performance of duties.

The library staff should take an active part in the instructional program of the institution. Specific provision should be made for formal instruction in the use of the library, possibly in collaboration with academic departments. The participation of the staff will also include informal individual instruction in the use of the library, advice to faculty members on bibliographical matters, work on various committees,

3 The State University, New York, has introduced for its teachers college libraries a formula which provides a basic college library staff of five professional positions and three positions of clerical grade for the first 750 full-time regular session students in for the frst attendance, each multiple of 500 additional regula session students requires the services of one addi tional professional position and one additional clerica position. The California State Department of Education, Division of State Colleges and Teacher Education, has also developed a staffing formula. (Instructions of July 1, 1955.) This formula is based on three factors: 1) a work-load factor for technica services based on detailed analysis of number of volumes shelved, inventoried, cataloged, bound, reclassified, recataloged, etc., 2) a factor for public service fed, recatalog, manning requirements based on library hours, numbers of public service points, type of manning re quired, etc., and 3) a factor for administration, percentage of the total of the other two. and the preparation of reading lists and special reports regarding library facilities or services. Such activities are part of the normal operation of a college library. Staff members with appropriate subject background may also help to bridge the gap between the library and the classroom by teaching a course in a subject area.

Members of the library staff must be chosen with great care, since they are to perform such a variety of important educational functions. The chief librarian in particular "needs the skill to direct a highly complex organization well, but his thinking and planning must be that of a teacher and scholar. ... He must know what scholarship is and what teaching entails. He must demonstrate the competence to merit the respect of his colleagues as an educator." 4

\section{Library Collections}

\section{A. Books and Periodicals}

The library's collection of books, periodicals, pamphlets, documents, newspapers, maps, microfilm, microcards, microprint, and other materials, must be so constituted and organized as to give effective strength and support to the educational program of the institution. The collection should meet the full curricular needs of undergraduate students and should be easily accessible to them. It should provide properly for the demands of graduate students in each field in which the institution offers the Master's degree. Also it should contain a generous selection of works to keep the members of the faculty abreast of the latest advances in modern scholarship and to assist them in their professional growth. If special programs of independent study involving a wide use of books are carried on, provision must be made for them in the library's collection.

In addition to the materials related directly or indirectly to the curriculum, the collection should contain the standard works which represent the heritage of civilization. These works should be continuously supplemented by a wide variety of books which combine timeliness with enduring value, chosen to arouse the intellectual curiosity

\footnotetext{
Middle States Association of Colleges and Secondary Schools, Evaluating the Library (Document no. 4.81, October 1957)
} 
of students and to satisfy their recreational reading needs.

There should be a strong and up-to-date reference collection consisting of the most authoritative reference works and bibliographies in all major fields of knowledge. This collection must not be restricted to subjects which form part of the curriculum, nor to publications in the English language.

The periodicals subscription list should be well balanced and carefully chosen to meet the requirements of students for collateral course reading, to provide in some measure for the research needs of advanced students and faculty, to keep the faculty informed of developments in their fields, and to afford thought-provoking general and recreational reading. 5 Newspaper subscriptions should provide news coverage at the national, regional, and local levels; they should include also one or more leading papers from abroad. Various political points of view should be represented. It is essential that the major journals and newspapers be kept and bound systematically or preserved in microtext form.

Printed, manuscript, and archival materials pertaining to the institution of which the library is a part should be collected and preserved.

The right of the librarian to select books and other materials representing all sides of controversial issues must be safeguarded by the institution, and any attempts at censorship from whatever sources or for whatever reasons must be resisted.

The quality of the library collections should not be sacrificed to unnecessary duplication of titles. However, works of lasting significance or of contemporary importance should be available in a sufficient number of copies to give students a fair opportunity to examine them thoroughly.

Obsolete materials, such as outmoded books, superseded editions, incomplete sets of longer works, broken files of unindexed journals, superfluous duplicates, and worn out or badly marked volumes, should be

5 Subscriptions should be checked against such an authoritative compilation as Classified List of Periodicals for the College Library; 4th edition, revised and enlarged by Evan Ira Farber (Boston: F. W. Faxon Company, 1957). College librarians should consult with their faculties about additions, if they consider the coverage inadequate. continuously weeded, with the advice of faculty members concerned. Gifts should be accepted only in case they add to the strength of the library collections and do not carry unreasonable restrictions. President, faculty, and librarian should join in developing a policy which clearly defines what kinds of gifts are desirable for the institution and why it is important educationally to integrate them with the regular collections except in rare instances.

If funds are allocated to departments, a substantial portion beyond fixed costs for periodicals and continuations should be reserved for direct assignment by the librarian. This portion should be large enough to provide for the purchase of reference works, general publications, expensive sets, books for recreational reading, and works which cross departmental lines, as well as for correcting weaknesses in the library's collection.

Library holdings should be checked frequently against standard bibliographies, both general and subject, as a reliable measure of their quality. ${ }^{6} \mathrm{~A}$ high percentage of listed titles which are relevant to the program of the individual institution, should be included in the library collections.

If The size of the library collections is large-

- Two comprehensive bibliographies which have proved to be particularly helpful for the purpose of self-evaluation, are the following: Catalogue of the Lamont Library Harvard College; prepared by Philip J. McNiff and members of the library staff (Cambridge, Mass.: Harvard University Press, 1953). Southern Association of Colleges and Secondary Schools, Commission on Colleges and Universities, The Classified List of Reference Books and Periodicals for College Libraries; edited br W. Stanley Hoole for College Libraries; edited by W. Stanley Hoole of-date, but still useful for checking the pre-war literature in some areas of the humanities is Charles $B$. Shaw, $A$ List of Books for College Libraries, $2 \mathrm{~d}$ edition (Chicago: ALA, 1931), and its supplement 19311938 (Chicago: ALA, 1940).

Some examples of excellent subject bibliographies are: The Concise Cambridge Bibliography of English Literature, 600-1950. edited by George Watson (Cambridge: University Press, 1958). Critical Bibliography bridge: University Press, 1958). Critical Bibliography of French Literature; edited by David C. Cabeen (3 vols. published thus far, Syracuse University Press, 1948-56) Foreign Affairs Bibliography (3 vols.: 1919.
$32,1932-1942,1942-1952$; edited by William L. Langer, Robert G. Woolbert, and Henry L. Roberts respectively, New York, Council on Foreign Relations, 19331955 , and kept up to date by the quarterly bibliog. raphies in Foreign Affairs). The Harvard List of Books in Psychology: compiled and annotated by the psychologists in Harvard University, 2d edition (Cambridge Mass. Harvard University Press bridge, Mass. Scientific, Medical and Technical Books Published in the $U . S . A$. to December 1956; edited by R
Hawkins, 2d edition (Washington, D. C.. 1958).

Also Lester Asheim and others. The Humanities Also Lester Asheim and others, The Humanities
and the Library (Chicago: ALA, 1957) and Louis R. and the Library (Chicago: ALA, 1957) and Louis $\mathrm{R}$. York: H. W. Wilson, 1951) should be checked, in the latter especially the section on teaching materials for general education on the college level. 
ly determined by the following major factors: (1) The extent and nature of the curriculum, (2) the number and character of graduate programs, (3) the methods of instruction, (4) the size of the undergraduate and graduate student body, both full-time and extension, and (5) the need of the faculty for more advanced materials which cannot be met conveniently by the use of research libraries in the area.

An analysis of small college library statistics $^{7}$ suggests that no library can be expected to give effective support to the instructional program if it contains fewer than 50,000 carefully chosen volumes. A steady growth is essential to any good college library. The rate of growth of the library collection may slow down, however, when the number of volumes reaches approximately 300,000 . Since there appears to be a correlation between the growth of the student body and the growth of the collection, there is a convenient measure based upon observation of the development of college libraries, which may serve as a guide: up to 600 students, 50,000 volumes; for every additional 200 students, 10,000 volumes. Part-time and extension students should be equated into full-time student figures for the purpose of such computations. It is, however, clearly understood, that these are minimal figures and that stronger institutions will demand considerably larger and richer collections.

The library's collections should be fully organized for use. The main catalog of the library should serve as a union catalog for all collections of the library whether housed in the main building or in college departments. The catalog should follow the Library of Congress and American Library Association cataloging codes as standards. Materials should be classified according to an accepted scheme in general usage and be subject to continual editing to keep the catalog abreast of modern technological developments. The catalog should also be constantly revised to keep it up-to-date in terminology.

\section{B. Audio-Visual Materials}

Audio-visual materials including films, filmstrips, recordings, and tapes are an in-

Tee the statistics published annually in the January issue of $C R L$. tegral part of modern instruction, and every college library must concern itself with them. The library should take the initiative for providing them, if no other agency on campus has been assigned this responsibility.

If the library is handling the program, it should be enabled to do so by special budgetary provisions, including those for additional staff. The program must be, both in its budget and its operation, an integral part of the whole of the library's functions. No audio-visual program can succeed without adequate facilities for the use of equipment and materials.

The librarian is bound by the same high standards of selection for films and recordings that he uses for books.

\section{BuILding}

Successful library service presupposes an adequate library building. The college library building should be centrally located and functionally designed. The type of building provided will depend on the character and the aims of the institution, but it should always meet the general demands of efficient operation. The residential college will have different building requirements from the college which serves commuters only. Every new building plan should include provisions for future expansion.

The size of the library building will depend on the type and size of institution which it serves, the instructional methods employed, the character of the collections and the number of volumes. In general, the seating capacity of a new building should be based on the anticipated growth over a twenty-year period. Accommodations for at least one-third of the student body will be essential. The changing concept of the role of the library in the academic community may make necessary an upward revision of this figure. Any particular situation will be further affected by the availability of other study facilities on campus.

Provision should be made for expansion of reading areas where students may have easy access to books and other materials. Book space, too, must be ample not only for the present, but for the foreseeable future as well. On principle, shelf space in a new building should be planned so that it allows at least for a doubling of the collection. Adequate housing must also be pro- 
vided for special materials such as current issues of periodicals, maps, pictures, art books, films, records, and microtexts.

Well-planned areas must be provided for any and all services which the library undertakes to furnish, e.g., well-arranged general circulation and reference areas, display space, rooms for listening to recordings, faculty studies, etc.

The efficient operation of the library also entails adequate quarters for the processes of ordering, preparation, cataloging, binding and mending, filing, and similar activities. Staff work-areas should comprise at least 125 square feet of floor space per person. Persons holding administrative positions should be given sufficient private office space. A staff lounge with simple kitchen facilities is highly desirable for the convenience of staff and visitors.

Much of the building's effectiveness depends on proper provisions for heat, light, and air. Sound-conditioning, air-conditioning, lighting, and decoration should be carefully planned so that students and faculty are encouraged to study in a cheerful and comfortable atmosphere. The proper control of humidity and heat should also be provided for books and materials, especially those that are rare and valuable.

College libraries should be equipped with well-designed library furniture of high quality. A variety of types of seating should be available including tables, carrels, individual desks, and comfortable lounge chairs away from tables. The table space of $3 \times 2$ feet per reader is recommended for general library use.

\section{The Quality of The Service and Its Evaluation}

In the field of librarianship, probably nothing is more difficult than assessing the quality of a college library, since it involves so many intangible factors. However, nothing is more important than to know how effective the library service actually is.

One way to measure the success of library activities is a continuous careful evaluation of the statistical records of the circulation department. Where the library has open shelves, these records will give only part of the picture. It is likely, however, that the library service to students is improving if the per capita figures of books on regular loan (two weeks or longer) to students show an upward trend over a considerable period of time. Surveys of what students are actually reading in the library at a given time, studies of books not supplied, reference questions not answered, and the character of interlibrary loans are additional bases for evaluating book collection and service. Such statistical investigations, however, must be made with caution and with full consideration of all factors involved. Much will depend on the teaching methods employed by the faculty. Therefore, it is particularly important to keep faculty members regularly informed on new publications, new acquisitions, etc. The librarian should work closely with them, as they plan new courses and develop new educational ideas, and assist them in gauging the actual and potential significance of the library resources for the teaching in their fields. The effectiveness of the instruction in the use of the library given by the staff will be reflected in how well the students avail themselves of the library resources.

Another approach is an evaluation of the library resources and services undertaken jointly by the teaching faculty and the library staff after careful planning. Such a self-evaluation should always lead to the strengthening of the ties between classroom and library. It is recommended that such self-studies be undertaken frequently. When necessary, the advice of outside experts should be secured.

\section{INTERLIBRARY COOPERATION}

By the nature of his work, the college librarian has to think, above all, of serving the faculty and students at his institution. But he should not lose sight of the important benefits to be derived from pooling the resources of his library with those of other interested libraries in the same community, region, state, and in the nation. This will have two salutary results. First, "it will greatly help the participating libraries to provide for their readers the broad and rich intellectual opportunities to which they are entitled."8 Second, such planned collabora-

${ }^{8}$ A Plan for Meeting College Library Problems: $A$ Report of the Regents' Committee on Integration of College and University Library Resources in New York State. (Albany, N. Y.: State Education Department, 1954), p. 18. This document contains a comprehensive plan for state-wide cooperation of college and university libraries. 
tion will make each dollar spent by cooperating libraries "go further than it would go if spent by an individual library."9

In particular, the college library should cooperate with other college, university, school and public library agencies in the community and the neighboring area for reference service to readers beyond the campus.

The librarian should investigate the possibility of cooperation with other libraries in the area, e.g., for the planned purchasing of materials to avoid unnecessary duplica-

- Metcalf, Keyes D, The Hampshire Inter-Library Center: $A$ Survey of I'ts Background and Its Problem and Recommendations for the Future. (South Hadley, Mass.: The Hampshire Inter-Library Center, 1957), p. 31 . tion and to increase the resources available to each cooperating library. On the other hand, the library should not seek to borrow from other libraries materials which are basic to the college program. ${ }^{10}$

In conclusion, it should be remembered that American higher education has entered upon an era of momentous change. These standards should be interpreted by college librarians and their authorities in a spirit that will enable the college libraries of the nation not only to maintain but to strengthen their position in the face of this new challenge.

10 For an excellent statement of the materials which a college library should own rather than borrow see the previously mentioned $A$ Plan for Meeting College Library Problems, pp. 8-9.

\section{Equipment Grants for}

\section{Junior College Libraries}

Junior college libraries will benefit from a new grant made to ACRL by Remington Rand, a division of the Sperry Rand Corporation. The corporation has made a grant of $\$ 7500$ to ACRL. It will be administered by a committee appointed from members of ACRL's Junior College Libraries Section. Allotments in sub-grants will be made to non-tax-supported junior college libraries for the purchase of standard library furniture and equipment manufactured by Library Bureau. Application forms will be distributed to all eligible libraries during September.

In announcing the grant Mr. Harold J. Syren, Sales Manager of Library Bureau, writes for Remington Rand: "The intent of the grant is to offer products which we manufacture to libraries that are non-tax-supported. We believe that this grant could serve a very useful purpose if limited to the junior colleges as they are springing up very rapidly and perhaps need help."

This is the fourth grant to ALA and ACRL by Remington Rand. Last year the sub-grants were allocated to college libraries and the program administered by a committee of the College Libraries Section of ACRL. The first two Remington Rand grants were administered by the ACRL Foundation Grants Committee.

"We are delighted that the Junior College Libraries Section will administer the Remington Rand grant for library equipment this year," says Miss Helen Mitchell, librarian of Clark College, Vancouver, Washington, chairman of the Junior College Libraries Section of ACRL 1959/60. "This is the first opportunity that the junior college librarians have had to participate in any of the grants administered by ACRL. Junior college libraries are assuming greater importance each year as the number of students in such institutions is rapidly increasing. We are grateful for the opportunity to show how libraries may be of increased service to these students by the use of the best possible equipment." 